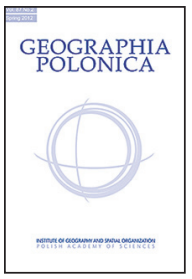

\title{
SCOTS PINE NEEDLE LITTER - CAN IT OFFER A MECHANISM FOR CARBON SEQUESTRATION? PRESENTATION OF A THEORY
}

\section{Björn Berg}

\author{
University of Helsinki \\ Department of Forest Sciences \\ P.O. Box 27, FIN-00014 Helsinki: Finland \\ e-mail address: BB0708212424@gmail.com
}

\begin{abstract}
Aim. The aim behind this work is: (i) to review the work on Scots pine needle litter in order to construct a model for the decomposition process, from litterfall until a stable fraction is left, (ii) suggest a simple regulating mechanism for its sequestration of carbon. Focus will be on foliar litter of Scots pine and the genus Pinus.

Discussion. The chemical composition of newly shed pine litter is in part determined by climate, e.g. mean annual temperature (MAT). Thus concentrations of nitrogen $(\mathrm{N})$ are higher - and those of manganese $(\mathrm{Mn})$ lower - with higher MAT. This may also influence the decomposition process. Mass loss of newly shed pine needle litter is positively influenced by climate (e.g. MAT), as well as by N and phosphorus (P) concentrations. In the late stage (above c. $30 \%$ accumulated mass loss) the influence of climate fades and those of lignin (Acid Unhydrolyzable Residue - AUR), N, and Mn are regulating the decomposition process. As the degradation of AUR dominates the decomposition process important parameters are those that influence the degradation of AUR, thus $\mathrm{N}$ and $\mathrm{Mn}$. In the humus-near organic matter limit values have been related to litter Mn concentration over a wide climate gradient. Thus, the higher the Mn concentration, the further the process goes and the smaller the stable fraction.

Conclusions. It appears that factors regulating the size of the stable litter fraction may be used as a tool on a larger geographical scale to predict carbon sequestration rates in pine forests.
\end{abstract}

\section{Key words}

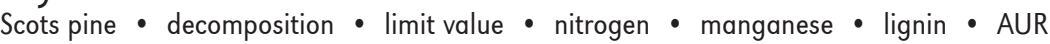

\section{Introduction}

Information about factors influencing patterns and mass-loss rates of decomposing litter is scattered and is seen to relate to litter of numerous species in a wide range of environments. It is reasonable to expect that the differences in chemical composition among litter species may create varying influences from different chemical components in the litter and thus differing mass-loss patterns. In addition, varying environments may add both climatic effects and effects on nutrient and substrate level.

To create a comprehensive picture of the decomposition process as such, the dynamics of litter nutrients and organic components and the litter's contribution to accumulation of soil organic matter (SOM) we may need at least to create a conceptual model and ideally one based on a single litter species. We may also ask what questions which are of interest to answer. For a long time it was generally accepted that litter decomposed 
completely and thus decomposition rates were of considerable interest.

Likewise, by tradition there appears to be a general opinion that climate governs decomposition on a regional scale, whereas litter chemical composition dominates the process on a local scale. However, the picture may in fact be more complicated. Meentemeyer (1978) and later Berg et al. (1993) showed a large-scale effect exerted by climate on decomposition rates of fresh plant litter. Such an effect is not general to all decomposition stages, but the role of a changing substrate may dominate - at least in some cases.

Howard and Howard (1974) described decomposition rates that approached zero, a phenomenon confirmed by Berg and Ekbohm (1991) and Berg et al. (1996). In such cases the accumulated mass loss approaches a final limit value for decomposition which can be described by an asymptotic function. So far such limit values have been described mainly for forest systems in boreal and temperate areas, not excluding them for subtropical and tropical ones.

Berg (2000) compared limit values for 106 sets of decomposing foliar litter from natural forest systems. Using litters representing a wide range in chemical composition he found a highly significant negative relationship between limit values and initial litter nitrogen $(\mathrm{N})$ concentrations. The levels of the estimated limit values have also been related to initial concentrations of other nutrients, such as manganese (Mn) (Berg et al. 1996). This approach makes it possible to quantify the remaining, recalcitrant mass in the very late stages and allows for further evaluation.

Thus, if litter species differ in limit values, i.e. they differ in fraction of remaining stable mass, then given a constant rate of litter fall, the buildup of soil organic matter should vary depending on the chemical composition of the falling litter, both within a species and between species. In fact, that long-term humus buildup and storage are possible was shown by Wardle et al. (1997) when they determined such a buildup had taken place for about 2900 years.

With the massive confirming information base from the Long-term Inter-site Decomposition Experiment Team (LIDET) that decomposing foliar litter leaves a stable residue (Harmon et al. 2009; Currie et al. 2010) we may expect the focus of interest to move towards explaining the retardation of the process, the limit value that defines the stable fraction, as well as the stability of the residue. Such a relative stability may be important from the point of view of the accumulation of carbon dioxide $\left(\mathrm{CO}_{2}\right)$ in humus.

The accumulation of SOM is a slow process that often spans generations of scientists, thereby causing continuity problems in following the buildup as well as the mechanisms controlling it. It nevertheless appears that a long-term buildup of SOM does take place. Using estimated stable fractions and litter-fall data, Berg et al. (2001) were able to reconstruct the buildup rate of the 2900-year old humus layer described by Wardle et al. (1997).

We may see that there are clear differences among litter species as regards a buildup of an organic layer. Vesterdal and Raulund-Rasmussen (1998) compared the amounts accumulated under 7 different tree species in a large block experiment covering Denmark. Lodgepole pine (Pinus contorta) stands appeared to give the largest formation of SOM; higher than in Norway spruce ( $\mathrm{Pi}$ cea abies) stands. In an evaluation of amounts of carbon in the organic layers across Sweden, Berg et al. (2009) found that forest of Scots pine (Pinus silvestris) sequestered larger amounts per year than that of Norway spruce $(p<0.0001)$, in spite of a higher foliar litter fall in the spruce forest.

The aim of this paper was to review and organize existing knowledge of the decomposition of Scots pine needle litter into a structure and create a system of factors influencing its decomposition from newly shed litter though to SOM. To this purpose I have reviewed existing information on Scots pine needle litter and other pine species.

\section{Discussion}

Of the factors influencing rates and patterns of litter decomposition, chemical composition (substrate quality), soil climate and soil-environment properties are important. It was thus indicated for pine forests (e.g. Meentemeyer \& Berg 1986) that a change in substrate quality of newly-shed litter could influence mass-loss rate as much as a difference in weather between years at the same site.

In a climatic gradient, the role of climate vs that of the gradually changing substrate quality with accumulated mass loss may become even more noticeable (e.g. Johansson et al. 1995). The direct effects of climate are not reviewed in the present paper. I intend to at least indicate an interaction 
between the factors of climate and chemical composition.

Considering the number of factors potentially influencing the decomposition process it may have a value to organize them in a conceptual model. Ideally, such a model ideally is based on one litter species or possibly species within the same genus, and I have mainly collected information on Scots pine needle litter, augmenting this with information on other pine species when needed.

It may be useful to comment on the terminology used. I refer repeatedly to the recalcitrant compound lignin in foliar litter. However, the traditional gravimetric analysis for this compound includes several others that are not native lignin and a suggested new term is Acid Unhydrolyzable Residue (AUR; Preston et al. 2009ab). It is the latter that has been used throughout this paper, unless reference is made to native lignin.

\section{Model for litter decomposition based on chemical changes during decomposition}

From a chemical point of view, fresh, newly-shed litter is very different from older, partly decomposed litter, and the changing chemical composition (during decomposition) influences both
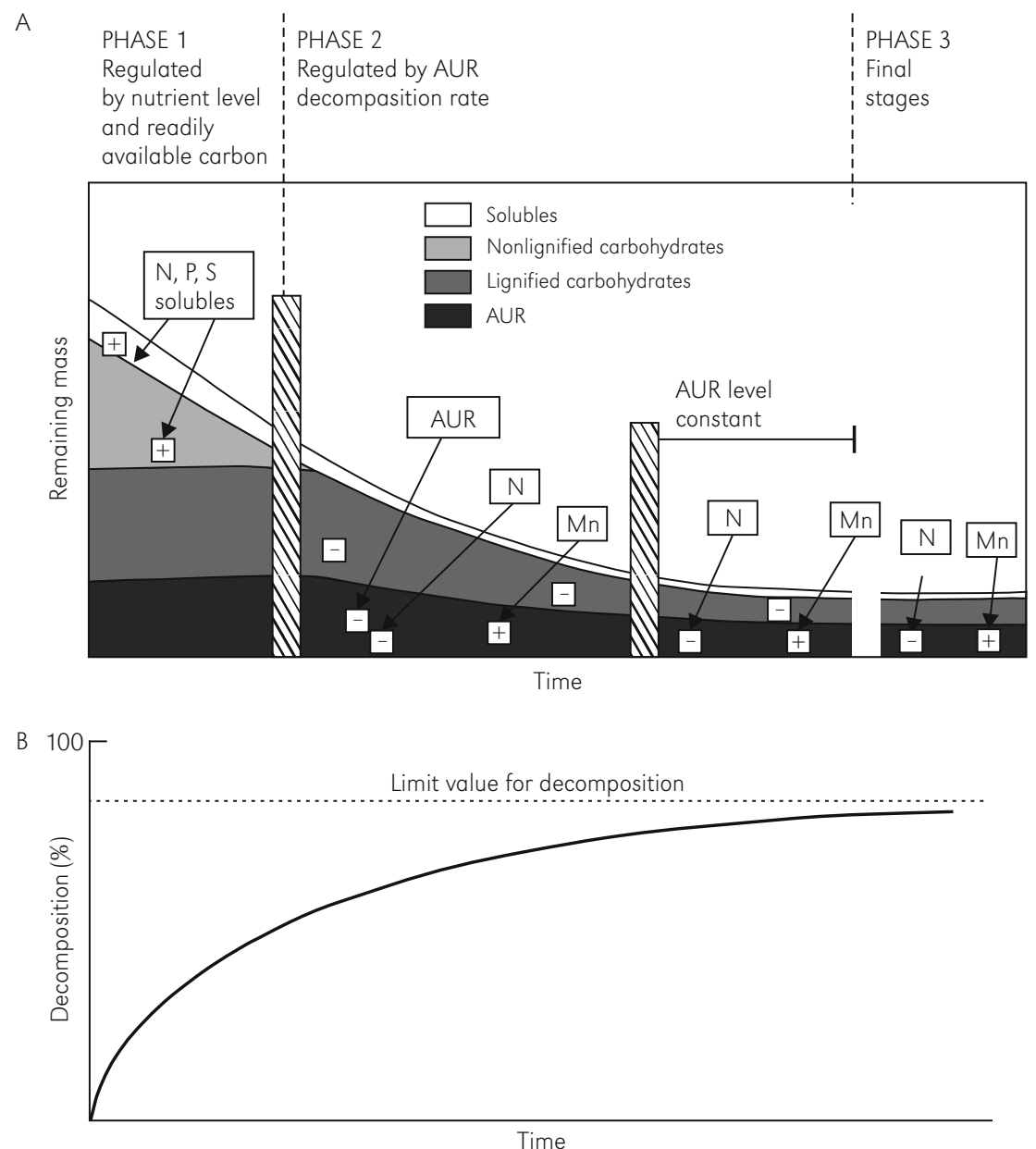

Figure 1. (A) Model for chemical changes and rate-regulating factors during decomposition. Modified from Berg and Matzner (1997). (B) Asymptotic model for estimating limit values for plant litter decomposition. Limit value indicated by the dashed line. A limit value is estimated from measured values for litter mass loss using equal (1) and gives a 'limit' at which the estimated mass loss is zero. It also may give a fraction of litter that is more recalcitrant.

Source: redrawn from Berg and Ekbohm (1991). 
rate-regulating factors and the microbial community. On the basis of their studies on Scots pine litter, Berg and Staaf (1980) set up a conceptual model dividing the decomposition process into two phases, with an early stage in which climate as well as concentrations of the major nutrients had a clear influence on decomposition rate. In that phase just unshielded (not lignified) organic compounds were decomposed. In a later phase, starting at the onset of AUR degradation, it is the decomposition of AUR that dominates over the influence of nutrients and thus controls the decomposition of litter overall (Fig. 1A).

With an increasing concentration of the resistant AUR, the rate continues to decrease and may even approach a limit value (Fig. 1B). We have used a development of the model (Berg \& Matzner 1997) to organize our discussion (Fig. 1A) and intend to discuss the early stage, the late stage, the humus-near (final) stage, as well as the stability of the remains at the humus stage, during which a limit value is reached.

\section{Decomposition in the early stage}

Substrate quality. In the early phase, amounts and concentrations of water-soluble substances decrease quickly (over a few months) before reaching relatively similar and stable levels (Berg et al. 1982). Free unshielded holocellulose is also degraded in this phase, whereas the more recalcitrant AUR (Acid Unhydrolyzable Residue) either does not decompose or does so to only a limited extent. Thus, its concentration starts to increase due to the decomposition of other main compounds. Also the concentrations of some nutrients such as $\mathrm{N}, \mathrm{P}$, and $\mathrm{S}$ also start to increase as do those of several heavy metals such as $\mathrm{Fe}, \mathrm{Pb}, \mathrm{Zn}$, and $\mathrm{Cu}$ (Berg \& McClaugherty 2008).

In the early phase, the mass-loss rate may be related to total concentrations of the major nutrients, such as $\mathrm{N}, \mathrm{P}$, and $S$, which are often limiting for decomposition rates in the cases of several species (Aber \& Melillo 1982; Berg \& Ekbohm 1991), among them Scots pine (Berg \& Staaf 1980). We may note a recent discovery by Kaspari et al. (2009) that even the highly soluble sodium $(\mathrm{Na})$ may be at least potentially limiting for litter decomposition in areas at inland sites (at a distance from sea-spray). Such an effect may apply at least in the early stage, in addition to those involving the main nutrients.

Climatic influences. It appears that climate may affect litter mass-loss rate in the case of newly-shed litter. For needle litter of Scots pine, it proved possible to demonstrate a clear influence on decomposition rate, by reference to the range of climates along a 2,000 km long gradient (Johansson et al. 1995; Fig. 2). Such effects of climate could thus be recorded for local and unified pine needle litter in pine forests with their relatively open canopy covers. The mass loss in the first year ranged from about 10.9\% $\mathrm{yr}^{-1}$ in northern Finland (close to the Barents Sea) to about $43.7 \% \mathrm{yr}^{-1}$ in northern Germany. The dominant rate-regulating factor was climate (as indicated by annual actual evapotranspiration (AET) or mean annual temperature (MAT), while none of the substrate-quality factors alone was significant.

\section{Decomposition in late stages}

Lignin (AUR) concentration and litter decomposition rates. Concentrations of the recalcitrant AUR fraction increase as decomposition proceeds, reaching relatively steady levels in the range 45 to 51\% (Berg \& McClaugherty 2008). These increasing concentrations showed partially

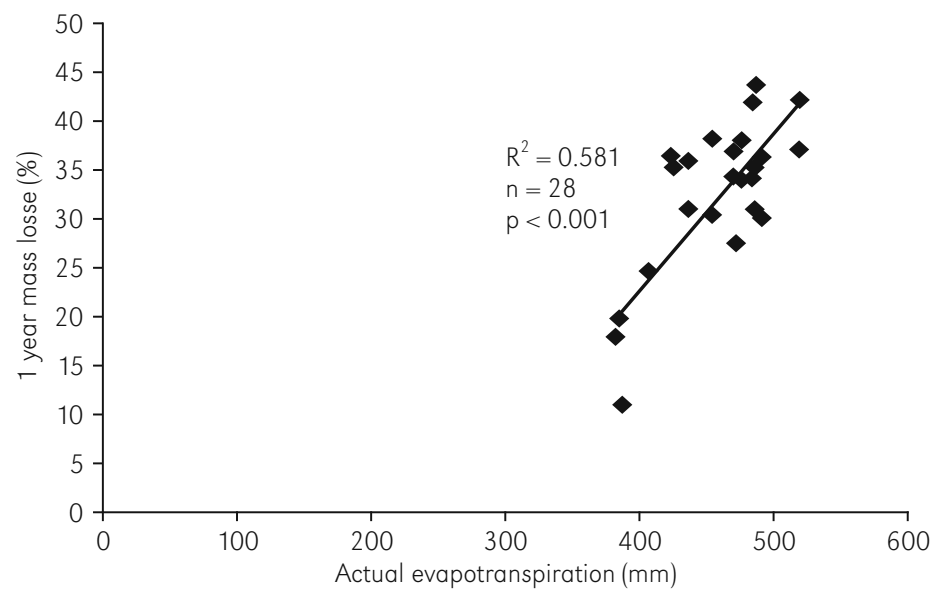

Figure 2. Linear relationship between annual actual evapotranspiration(AET) and first-year mass loss. Data cover Northern Europe, from northern Germany to the Arctic Circle.

Source: from Johansson et al. 1995 
linear relationships with accumulated mass loss (Berg et al. 1984). Concentrations of $\mathrm{N}$ also increase linearly with accumulated mass-loss (Berg \& McClaugherty 2008). Thus, as decomposition proceeds, litter becomes enriched in AUR and N (Berg \& Matzner 1997), as well as heavy metals.

Increased AUR concentrations with litter decomposition are shown to depress decomposition rates (e.g. Johansson et al. 1995). The rate of decomposition rate of remaining litter would then be under the dominant influence of lignin (AUR) degradation rates, as the cellulose in the remaining parts is shielded by it.

The suppressing effect of AUR on litter mass-loss rates can be said to conform to a linear relationship (Fig. 3A) in the late stage, this already starting at c. $20-30 \%$ accumulated mass-loss in the case of pine litter (Fig. 3A). Johansson et al. (1995) observed that the slope and intercept of this negative relationship varied among sites with different climates. For northern sites, slopes were gentle, showing that AUR concentration had only a very limited effect. The smallest impact of AUR concentration on mass-loss rates was thus found near the Arctic Circle (where long-term average AET was about 385-390 mm), whereas in Northern Germany the rate-regulating effect associated with AUR was greater (Fig. 3B). The steepest slopes were thus obtained for the southern sites, which were warmer and wetter (AET values being 509 mm for site 8 and $560 \mathrm{~mm}$ for site 13). These sites had initially higher mass-loss rates than the more northern ones (Fig. 3B). Thus, whereas the slope for site \#13 was $-0.250 \mathrm{mg}^{-1}$, the slopes were -0.022 and $-0.018 \mathrm{mg}^{-1}$ close to the Arctic Circle. The slopes for sites in the south (\# 8) and central Sweden (\# 6:51) were in between (Fig. 3B).

In a development of this work, Johansson et al. (1995) compared slopes for the significant relationships between AUR concentration and annual mass loss for 11 sites along the full length of the climatic transect. The effect of AUR concentration on litter mass-loss rate thus varied with site climate and this relative effect was negatively related with AET. Johansson et al. (1995) even found a highly significant relationship between slope and AET (Fig. $4 ; R^{2}=0.563$ ) further supporting the idea of an interaction between site climate and substrate quality.

Manganese and nitrogen concentrations are critical for the degradation of lignin (AUR). It has been suggested that, in the late decomposition stage, the very slow degradation of AUR is rate-retarding. A reason for this is that
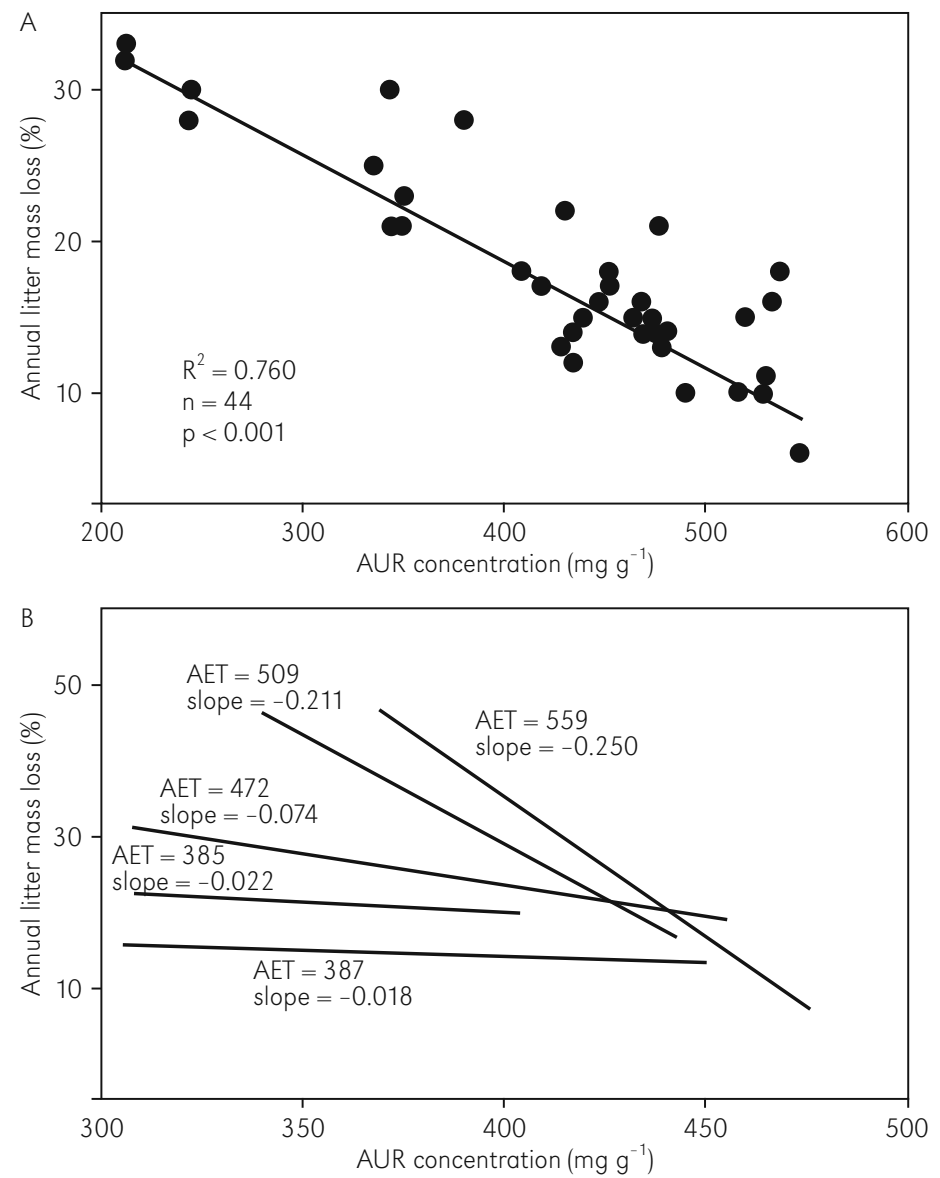

Figure 3. Linear relationships between AUR concentration in decomposing Scots pine needle litter and annual litter mass loss. (A) Available data from one Scots pine stand. (B) Available data from five climatically different sites (Scots pine stands) with the AET values 385, 387, 472, 509, and $560 \mathrm{~mm}$ for sites 2, 3, 6:51, 8 and 13, respectively.

Source: Berg and McClaugherty (2008). 
AUR concentration has been negatively related with annual mass loss of litter (e.g. Fig. 3A). Although the degradation of AUR appears to suppress the decomposition rate for litter, the degradation of AUR is itself influenced indirectly by several nutrients (e.g. Fe, Mn, $N)$, through their influence on degrading microorganisms (e.g. Eriksson et al. 1990). Of the influencing nutrients, $\mathrm{Fe}$ is often in excess. Those that are more limiting may better indicate their effects, and I will focus on $\mathrm{Mn}$ and $\mathrm{N}$. However, we cannot neglect the possibility of complicated interactions applying to two or possibly all three nutrients.

The lignolytic enzyme $\mathrm{Mn}$ peroxidase $(\mathrm{MnP})$ is produced by a majority of all wood- degrading basidiomycetes that cause white-rot, as well as by various soil-litter colonizing saprotrophic fungi. Among the lignolytic enzymes $\mathrm{MnP}$ is probably the most widespread peroxidase produced by these fungi (Hofrichter 2002). Manganese is essential for the activity of $\mathrm{MnP}$ and enhances its production (Perez \& Jeffries 1992). It is also involved in the regulation of other lignolytic enzymes. The role of $\mathrm{MnP}$ is to oxidize $\mathrm{Mn}^{2+}$ ions, which are found in plant residues, wood and soil, to highly reactive $\mathrm{Mn}^{3+}$ ions. These are in turn stabilized by organic acids also produced by these fungi (e.g. Archibald \& Roy 1992).

There are few studies available concerning $\mathrm{Mn}$ and litter decomposition. Berg et al. (2007) showed a clear positive relationship between $\mathrm{Mn}$ concentration and annual mass loss using mainly litter of Norway spruce, Scots pine, and lodgepole pine $\left(R^{2}=0.151, n=136, p<0.001\right)$. Available data for lodgepole pine litter showed a significant, positive relationship for $\mathrm{Mn}$ concentration $\left(R^{2}=0.281\right.$, $n=16$; Tab. 1). Even if the effect of $M n$ does not encompass the whole late stage, it may have an increasing effect as decomposition proceeds. In a study using mainly coniferous litter, available data indicate that, as litter decomposition progressed, the level of $\mathrm{Mn}$ became increasingly important the further the decomposition proceeded (Tab. 2; Berg et al. 2007).
Table 1. Relationships between annual litter mass loss and litter Mn and AUR concentrations in the late stage of decomposition.

\begin{tabular}{|l|c|c|c|}
\hline & $R^{2}$ & $R^{2}{ }_{\text {odj }}$ & $p<$ \\
\hline \multicolumn{4}{|c|}{ All lodgepole pine data (three sites) } \\
AUR & 0.281 & 0.230 & 0.05 \\
Mn + AUR & 0.424 & 0.383 & 0.01 \\
& 0.455 & 0.416 & 0.01 \\
\hline
\end{tabular}

Mass-loss was calculated for each year, and concentrations of $\mathrm{Mn}$ and AUR were those at the start of each year. A dataset with lodgepole pine needle litter from three very similar sites (Anundberget, Kappsjön, and Jädraås $n=16$ ) was investigated. The $\mathrm{Mn}$ concentration range was 0.71 to $2.9 \mathrm{mg} \mathrm{g}^{-1}$. Source: Berg et al. (2007).

During late stages of decomposition there is a clear negative relationship between $\mathrm{N}$ concentration and AUR mass-loss rate, as well as between $N$ concentration and litter mass-loss rate. Berg and Ekbohm (1991) found that the AUR decomposition rate was lowest for $\mathrm{N}$-rich litters and highest for $\mathrm{N}$-poor ones. They also found a clearly significant and negative relationship between $\mathrm{N}$ concentration and AUR decomposition which was common to 7 types of litter. They fitted a highly significant linear model for AUR vs. the $\mathrm{N}$ concentration of the litters $\left(R^{2}=0.677\right)$.

The empirical relationship of $\mathrm{N}$ as a rate-suppressing factor could be supported by causal relationships based on two phenomena. These also help to explain why mass-loss rates of the sulfuric-acid lignin fraction differed among litters. Keyser et al. 
Table 2. Comparison of $\mathrm{R}^{2}$ adj for the relationships between annual mass-loss and concentration of manganese in decomposing litter in the late stage.

\begin{tabular}{|c|c|c|c|c|c|}
\hline $\begin{array}{c}\text { AUR concn. range } \\
\left(\mathrm{mg} \mathrm{g}^{-1}\right)\end{array}$ & $\mathrm{R}^{2}$ & $\mathrm{R}_{\text {odj }}^{2}$ & $\mathrm{p}<$ & $\mathrm{n}$ & $\begin{array}{c}\text { Mn concn. range } \\
\left(\mathrm{mg} \mathrm{g}^{-1}\right)\end{array}$ \\
\hline $277-509$ & 0.151 & 0.145 & 0.001 & 136 & $0.04-7.69$ \\
$>350$ & 0.182 & 0.175 & 0.001 & 115 & $0.04-7.69$ \\
$>400$ & 0.215 & 0.206 & 0.001 & 94 & $0.24-7.69$ \\
$>450$ & 0.360 & 0.349 & 0.001 & 62 & $0.24-7.69$ \\
$>475$ & 0.457 & 0.441 & 0.001 & 35 & $0.24-7.69$ \\
\hline
\end{tabular}

Regressions were made using a stepwise more narrow interval in AUR concentrations. As the AUR concentrations increase with increasing accumulated mass-loss, AUR concentrations, in addition to giving the concentration of a substrate, also index the decomposition level of the litter. Available data were used.

Source: Berg et al. (2007).

(1978) found that low-molecular N compounds repressed the formation of lignolytic enzymes in one species of white-rot fungus. There now appear to be several species in which this kind of repression is present (Eriksson et al. 1990). As a further rate-regulating phenomenon, products of lignin degradation may react with ammonia or amino acids to form recalcitrant complexes (Nömmik \& Vahtras 1982) which make up part of the AUR complex.

The very late stages and the "limit value" concept. Howard and Howard (1974) and Berg and Ekbohm (1991) described limit values (Fig. 1B) that were different with litter from different species. A "limit value" is estimated using a function that gives an asymptotic value for the accumulated mass loss. In this regard, Berg and Ekbohm (1991) suggested:

$$
L_{t}=m\left(1-\mathrm{e}^{-k t / m}\right)
$$

where;

$L_{t}-$ is the accumulated mass loss (in percent),

$t$ - time in days,

$k$ - the decomposition rate at the beginning of decay,

$m$ - the asymptotic level that the accumulated mass loss will ultimately reach, normally not $100 \%$ and often considerably less.

The $k$ of this function should not be directly compared to rate constants estimated with other models.

From literature data, Berg (2000) estimated a total of

Source: Berg (2000).
106 limit values for foliar litter decomposing in natural systems. When regressing these against concentrations of nutrients and AUR, he found that N concentration gave a highly significant and negative relationship $\left(R^{2}=0.323, n=106, p<0.001\right.$; Fig. 5). The possible causal background to this relationship between limit values and $\mathrm{N}$ were discussed above. The fact that in this large dataset the relationship with $\mathrm{N}$ concentration was significant may indicate a general effect of $\mathrm{N}$ over a good number of species, in that case 21 , i.e. both deciduous and coniferous litter and ecosystems in boreal and temperate forests.

However, in a study on limit values for litter from trees of just one genus, namely Pinus (and mainly Scots pine), Berg et al. (2010), used backward elimination and local litter along a climatic gradient to determine that initial litter Mn concentration was the only significant factor where limit values were

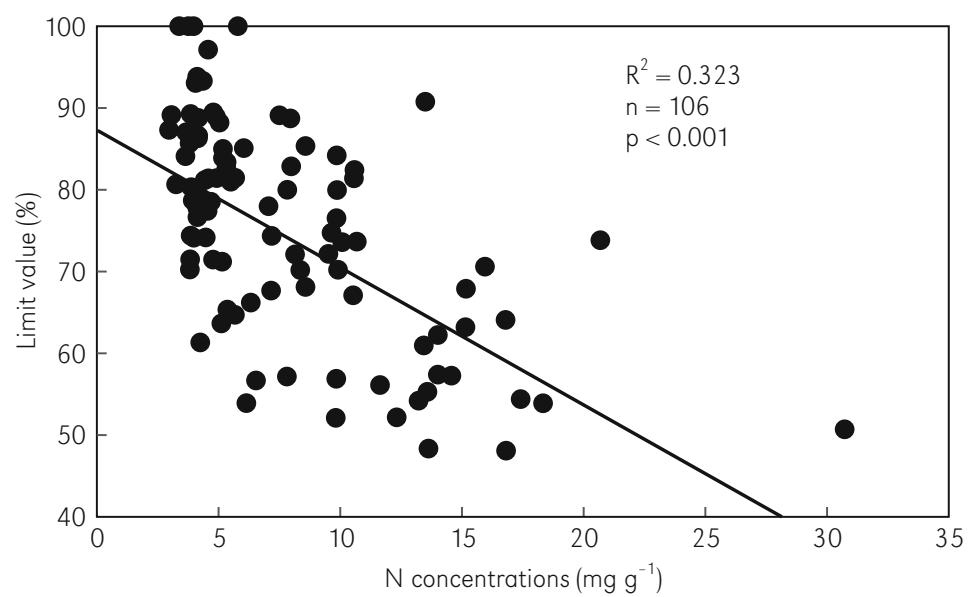

Figure 5. Linear relationship between limit values for decomposition and initial concentrations of $\mathrm{N}$ in foliar litter. Natural systems were used and data encompass 21 litter types/species. 
concerned. The backward elimination procedure simply removed non-significant factors in a stepwise fashion. Using their data, we applied a quadratic function of the type $-X^{2}+X$ and obtained a highly significant relationship (Fig. 6). That relationship was based on litter from four pine species and litter $\mathrm{Mn}$ concentrations ranging from 0.03 to $3.1 \mathrm{mg} \mathrm{g}^{-1}$. In addition the data from the aforementioned authors originated from a climate gradient with MAT ranging from -0.7 to $17^{\circ} \mathrm{C}$. In contrast to the above finding for 21 deciduous and coniferous species there was no significance regarding $N$ in the dataset confining itself to pine litter. Of the 8 substrate-quality factors and 2 environmental ones, it was $\mathrm{Mn}$ concentration that was left as the single factor.

The limit value as such is still mainly an empirical finding, although we have obtained both a causal relationship and a highly significant relationship to Mn concentration, at least for Pinus litter.

It has already been noted that litter becomes increasingly enriched in AUR, as well as AUR recombination products whose stability is influenced by $\mathrm{N}$ and Mn. However, among the substrate factors we cannot either neglect the possible role of increasing concentrations of heavy metals, such as $\mathrm{Cu}$, $\mathrm{Pb}, \mathrm{Fe}$ and $\mathrm{Zn}$. Such concentration increases may be correlated with those concerning $N$ and thus be in a position to account for part of the significant relationship. In general, pine litter appears to manifest linear net release of $\mathrm{Mn}$ (B. Berg, unpubl.). Being linear to accumulated mass-loss, it may well be correlated with the above factors. For all cases ( $\mathrm{Mn}, \mathrm{N}$, and heavy metals) we may note causal relationships with retarded decomposition, and possibly the study of Berg et al. (2010) could exclude $N$. Still the role of the main heavy metals needs to be clarified, though the fact that this may also relate to site properties needs to be borne in mind.

How much do certain critical chemical components vary in needle litter across

\section{a region, and among different pine species?}

That litter nutrients may vary with climate was reported by Berg, Calvo de Anta et al. (1995), who found that the concentration of $\mathrm{N}$ in pine needle litter was positively related to site AET and MAT, while that of $\mathrm{Mn}$ was related negatively. This was seen for both Scots pine as a single species and for available pine spp. data. Among pine species in Europe the lowest values for $\mathrm{N}$ concentrations were found around and to the north of the Arctic Circle (c. $3 \mathrm{mg} \mathrm{g}^{-1}$ ), this comparing with concentrations of up to $8 \mathrm{mg} \mathrm{g}^{-1}$ in natural systems further south (Berg et al. 1995). We may note that the range of $\mathrm{Mn}$ concentrations thus far observed extends from $0.03 \mathrm{mg} \mathrm{g}^{-1}$ for Aleppo pine in Libya to $3.1 \mathrm{mg} \mathrm{g}^{-1}$ in the case of Scots pine at the Arctic Circle in Sweden (Fig. 7). For Scots pine alone, the range noted is 0.26 to $3.1 \mathrm{mg} \mathrm{g}^{-1} \mathrm{Mn}$ (Berg, Calvo de 
Anta et al. 1995) and these observations were followed up by Oleksyn et al. (2003), who mainly used the same climatic gradient with Scots pine and compared $\mathrm{N}$ concentrations in green Scots pine needles with those in brown ones. They suggested a retrieval mechanism for $\mathrm{N}$ operating more intensively under a colder and drier climate. For $\mathrm{Mn}$, the variation with $A E T$ and MAT appears to be an empirical observation.

Berg and McClaugherty (2008) reported that there were clear differences among pine species. For example, lodgepole pine litter had higher Mn and AUR concentrations than Scots pine needle litter, the $\mathrm{N}$ concentrations were similar. It nevertheless appears that litter formed from the needles of different Pinus species are sufficiently similar to allow for aggregation into a larger group.

What do we know about the stability of the litter residue? If the hypothesis presented above holds true, it will prove possible to distinguish differences in humus-buildup rates among tree species, provided that suitable test systems are found. Although limit values for litter mass-loss have been estimated for a variety of litters using asymptotic functions, we may not conclude that such limit values indicate that the remaining organic matter is completely non-degradable. Instead, the residual organic matter could very well consist of a moderately stabilized fraction that decomposes very slowly, or else a fraction that just does not decompose in a given environment. However, this would not mean that the discovery of an apparent final mass-loss value should be considered trivial, especially if the limit value can indeed be related to given climatic and litter properties, e.g., Mn concentration or environmental factors. Two studies using limit values and litterfall data have allowed for the reconstruction of build-up rates in relation to humus layers (Berg et al. 1995b, 2001).

The recalcitrant fraction estimated using limit values (Fig. 6B) has been applied in two separate studies to estimate humus build-up rates. In one case (Berg, McClaugherty et al. 1995), accumulation rate was estimated for a Scots pine monoculture, c. 130 years old. In another paper (Berg et al. 2001) the accumulation rates were estimated for pine- and spruce-dominated forest on isolated islands on which humus had accumulated for almost 3,000 years. While it is evident that further test systems are needed, this paper has offered a review of relevant data, and suggested a basic mechanism for limit values, and thus for recalcitrant litter fractions. The data cover Western Europe, but we cannot preclude a certain generality of application, at least for Pinus spp. across Europe.

\section{Conclusions}

It appears that the factors regulating the stable fraction of litter from pine (Pinus) spp. may be referenced on a larger geographical scale to predict carbon sequestration rates in pine forests. A geographical scale the size of Europe is not precluded.

\section{Acknowledgements}

The constructive comments of two anonymous reviewers are gratefully acknowledged.

Editors' note:

Unless otherwise stated, the sources of tables and figures are the author(s), on the basis of their own research. 


\section{References}

Aber J.D., Melillo J.M., 1982. Nitrogen immobilization in decaying hardwood leaf litter as a function of initial nitrogen and lignin content. Canadian Journal of Botany, vol. 60, no. 11, pp. 2263-2269.

Archibald F., Roy B., 1992. Production of manganic chelates by laccase from the lignin-degrading fungus Trametes (Coriolus) versicolor. Applied and Environmental Microbiology, vol. 58, no. 5, pp. 1496-1499.

BERG B., 2000. Litter decomposition and organic matter turnover in northern forest soils. Forest Ecology and Management, vol. 133, no. 1, pp. 13-22.

Berg B., Berg M.P., Bottner P., Box E., Breymeyer A., Calvo de Anta R., Couteaux M., Escudero A., Gallardo A., Kratz W., Madeira M., Mälkönen E., MCClaugherty C., Meentemeyer V., Muñoz F., Piussi P., Remacle J., Virzo De Santo A., 1993. Litter mass loss in pine forests of Europe and Eastern United States: some relationships with climate and litter quality. Biogeochemistry, vol. 20, iss. 3, pp. 127-159.

Berg B., Calvo de Anta R., Escudero A., Johansson M.B., Laskowski R., Madeira M., McClaugherty C., Meentemeyer V., Reurslag A., Virzo De Santo A., 1995. The chemical composition of newly shed needle litter of Scots pine and some other pine species in a climatic transect. $X$. Long-term decomposition in a Scots pine forest. Canadian Journal of Botany, vol. 73, no. 9, pp. 1423-1435.

Berg B., Davey M.P., De Marco A., Emmett B., FalturI M., Hobbie S.E., Johansson M.-B., LIU C., MCClaugherty C., Norell l., Rutigliano F.A., VesterDAL L., VIRZO DE SANTO A., 2010. Factors influencing limit values for pine needle litter decomposition: a synthesis for boreal and temperate pine forest systems. Biogeochemistry, vol. 100, pp. 57-73.

Berg B., EkBOHM G., 1991. Litter mass-loss rates and decomposition patterns in some needle and leaf litter types. Long-term decomposition in a Scots pine forest. VII. Canadian Journal of Botany, vol. 69, no. 7, pp. 1449-1456.

Berg B., Ekbohm G., Johansson M.-B., McClaugherty C., Rutigliano F., Virzo De Santo A., 1996. Maximum decomposition limits of forest litter types: a synthesis. Canadian Journal of Botany, vol. 74, no. 5, pp. 659-672.

Berg B., Ekbohm G., McClaugherty C.A., 1984. Lignin and holocellulose relations during long-term decomposition of some forest litters. Long-term decomposition in a Scots pine forest. IV. Canadian Journal of Botany, vol. 62, no. 12, pp. 2540-2550.

Berg B., Hannus K., Popoff T., Theander O., 1982. Changes in organic-chemical components of needle litter during decomposition. Long-term decomposition in a Scots pine forest. I. Canadian Journal of Botany, vol. 60, iss. 8, pp. 1310-1319.

Berg B., Johansson M.-B., Nilsson A., Gundersen P., Norell L., 2009. Sequestration of carbon in the humus layer of Swedish forests - direct measurements. Canadian Journal of Forest Research, vol. 39, no. 5, pp. 962-975.

Berg B., Matzner E., 1997. Effect of $N$ deposition on decomposition of plant litter and soil organic mat ter in forest systems. Environmental Reviews, vol. 5 , no. 1, pp. 1-25.

Berg B., McClaugherty C., 2008. Plant litter. Decomposition, humus formation, carbon sequestration. Berlin-Heidelberg: Springer-Verlag, 338 pp.

Berg B., McClaugherty C., Virzo De Santo A., JoHANSSON M.-B., EKBOHM G., 1995. Decomposition of litter and soil organic matter - can we distinguish a mechanism for soil organic matter buildup? Scandinavian Journal of Forest Research, vol. 10, iss. 1-4, pp. 108-119.

Berg B., McClaugherty C., Virzo De Santo A., JoHnson D., 2001. Humus buildup in boreal forests - effects of litter fall and its $N$ concentration. Canadian Journal of Forest Research, vol. 31, no. 6, pp. 988-998.

Berg B., StaAf H., 1980. Decomposition rate and chemical changes of Scots pine needle litter. II. Influence of chemical composition [in:] T. Persson (ed.), Structure and function of northern coniferous forests: an ecosystem study, Ecological Bulletins, vol. 32, pp. 373-390.

Berg B., Steffen K.T., McClaugherty C., 2007. Litter decomposition rates is dependent on litter Mn concentration. Biogeochemistry, vol. 85, pp. 29-39.

Currie W.S., Harmon M.E., Burke I.C., Hart S.C., PartON W.J., Silver W., 2010. Cross-biome transplants of plant litter show decomposition models extend to a broader climatic range but lose predictability at the decadal time scale. Global Change Biology, vol. 16, iss. 6, pp. 1744-1761.

Eriksson K.-E.L., Blanchette R.A., Ander P., 1990. Microbial and enzymatic degradation of wood and wood components. Berlin-New York: Springer-Verlag, $407 \mathrm{pp}$.

harmon M.E., Silver W.L., fasth B., Chen H., Burke I.C., Parton W.J., Hart S.C., Currie W.S. and LIDET, 2009. Long-term patterns of mass loss during the decomposition of leaf and fine root litter: an intersite comparison. Global Change Biology, vol. 15, iss. 5, pp. 1320-1338.

HOfRICHTER M., 2002. Review: lignin conversion by manganese peroxidase (MnP). Enzyme and Microbial Technology, vol. 30, iss. 4, pp. 454-466. 
Howard P.J.A., Howard D.M., 1974. Microbial decomposition of tree and shrub leaf litter. 1. Weight loss and chemical composition of decomposing litter. Oikos, vol. 25, no. 3, pp. 341-352.

Johansson M.-B., Berg B., Meentemeyer V., 1995. Litter mass-loss rates in late stages of decomposition in a climatic transect of pine forests. Long-term decomposition in a Scots pine forest. IX. Canadian Journal of Botany, vol. 73, iss. 10, pp. 1509-1521.

Kaspari M., Yanoviak S.P., Dudley R., Yuan M., ClaY N.A., 2009. Sodium shortage as a constraint on the carbon cycle in an inland tropical rainforest. Proceedings of the National Academy of Sciences of the United States of America, PNAS, vol. 106, no. 46, pp. 19405-19409.

Keyser P., KIRK T.K., ZeikUs J.G., 1978. Ligninolytic enzyme system of Phanerochaete chrysosporium: synthesized in the absence of lignin in response to nitrogen starvation. Journal of Bacteriology, vol. 135, no. 3, pp. 790-797.

Meentemeyer V., 1978. Macroclimate and lignin control of litter decomposition rates. Ecology, vol. 59, iss. 3, pp. 465-472.

Meentemeyer V., Berg B., 1986. Regional variation in rate of mass loss of Pinus sylvestris needle litter in Swedish pine forests as influenced by climate and litter quality. Scandinavian Journal of Forest Research, vol. 1, no. 2, pp. 167-180.

NÖMmIK H., VAHTRAS K., 1982. Retention and fixation of ammonium and ammonia in soils [in:] F.J. Stevenson (ed.), Nitrogen in agricultural soils, Agronomy
Monographs, no. 22, Madison: Agronomy Society of America, pp. 123-171.

Oleksyn J., Reich P.B., Zytkowiak R., Karolewski P., TJOelKer M.G., 2003. Nutrient conservation increases with latitude of origin in European Pinus sylvestris populations. Oecologia, vol. 136, iss. 2, pp. 220-235.

Perez J., Jefrries T.W., 1992. Roles of manganese and organic acid chelators in regulating lignin degradation and biosynthesis of peroxidases by Phanerochaete chrysosporium. Applied and Environmental Microbiology, vol. 58, iss. 8, pp. 2402-2409.

Preston C.M., Nault J.R., Trofymov J.A., Smyth C., 2009a. Chemical changes during 6 years of decomposition of 11 litters in some Canadian forest sites. Part 1. Elemental composition, tannins, phenolics and proximate fractions. Ecosystems, vol. 12, iss. 7, pp. 1053-1077.

Preston C.M., Nault J.R., Trofymov J.A., $2009 \mathrm{~b}$. Chemical changes during 6 years of decomposition of 11 litters in some Canadian forest sites. Part $2 .{ }^{13} \mathrm{C}$ abundance, solid-state ${ }^{13} \mathrm{C}$-NMR spectroscopy and the meaning of "lignin". Ecosystems, vol. 12, iss. 7, pp. 1078-1102.

Vesterdal L., Raulund-Rasmussen K., 1998. Forest floor chemistry under seven tree species along a soil fertility gradient. Canadian Journal of Forest Research, vol. 28, no. 11, pp. 1636-1647.

Wardle D.A., Zackrisson O., Hörnberg G., Gallet C., 1997. The influence of island area on ecosystem properties. Science, vol. 227, pp. 1296-1299.
(C) Björn Berg

(C) Geographia Polonica

(C) Institute of Geography and Spatial Organization,

Polish Academy of Sciences, Warsaw, 2012 
http://rcin.org.pl 